\title{
WZORZEC STRUKTURY CHARAKTERYSTYKI POSTACI I JEGO REALIZACJE W PRACACH OBCOKRAJOWCÓW UCZĄCYCH SIĘ JEZYKA POLSKIEGO NA POZIOMIE A2
}

\begin{abstract}
Słowa kluczowe: charakterystyka postaci, kompetencja tekstowa, kompetencja tekstotwórcza, kompozycja, metodyka nauczania, nauczanie języka polskiego jako obcego, obcokrajowiec

Streszczenie. Artykuł podejmuje pewne zagadnienia tekstowe związane z produkcją form pisemnych na lekcjach języka polskiego jako obcego. Jest próbą analizy kompozycji charakterystyk przyjaciela pisanych przez słuchaczy Studium Języka Polskiego dla Cudzoziemców UŁ. Ukazuje globalną strukturę tych prac, ich podziały formalne, delimitację tekstu oraz użycie wypowiedzi metatekstowych. Bada ponadto stopień opanowania przez studentów treści nauczania, które nabyli podczas zajęć omawiających technikę pisania charakterystyki bezpośredniej. Podaje przykłady ćwiczeń dydaktycznych przydatnych cudzoziemcom w prawidłowej realizacji wzorca omawianej formy pisemnej.
\end{abstract}

\section{WSTĘP}

Wypowiedzi pisemne uczniów są od lat przedmiotem refleksji naukowej. Prowadzono choćby rozważania poświęcone stylowi (Saloni 1975; Kowalikowa 1999; Jaroszak 2003; Zok-Smoła 2013), kompetencji językowej uczących się (Saloni 1968, 1971; Pilich 1972; Kaczorowska, Ruszkowski 1996), różnicom między językiem pisanym a mówionym (Małkowska-Zegadło 1983), a także badaniu innych cech (Kubik 1995).

O wysokiej randze tworzenia różnorodnych form wypowiedzi pisemnych, zarówno na lekcjach języka polskiego jako pierwszego, jak i obcego, świadczy duża liczba poradników, kompendiów, przewodników, vademeców traktujących

*justine.so@vp.pl, Uniwersytet Łódzki, Wydział Filologiczny, Instytut Filologii Polskiej i Logopedii, Zakład Lingwistyki Stosowanej i Kulturowej, ul. Pomorska 171/173, 90-236 Łódź; Uniwersytet Łódzki, Studium Języka Polskiego dla Cudzoziemców, ul. Jana Matejki 21/23, 90-001 Łódź. 
o uczeniu lub doskonaleniu sprawności pisania. Ich autorzy wiążą tę umiejętność z radzeniem sobie w szkole, aktywnością zawodową czy społeczną (Przygoda 2015, s. 5), nazywając ją rzemiosłem, którego trzeba i można się uczyć (Maćkiewicz 2010, s. 9), choć to zadanie żmudne i wymagające długotrwałej praktyki (Kuziak, Rzepczyński 2002, s. 5).

Badania nad budową poszczególnych form pisemnych wiążą się z pojęciem kompetencji tekstowej lub tekstotwórczej autorów. Kompetencję tekstową definiuje się jako „zdolność do produkowania i odbierania różnych typów zdarzeń komunikacyjnych” (Duszak 1998, s. 199) i nazywa „świadomością tekstową, która wynika z rozumienia, czym jest tekst, jakie rządzą nim prawa, co jest najistotniejsze w jego organizacji" (Nowak 2014, s. 123). Kompetencja tekstotwórcza zaś to „ludzka umiejętność tworzenia i odbierania spójności tekstu oraz zdolność postrzegania podziałów w uniwersum tekstów" (Tabisz 2006, s. 65).

\section{CEL PODJĘTYCH BADAŃ}

Celem artykułu jest przedstawienie wzorca tekstowego charakterystyki bezpośredniej pisanej przez obcokrajowców uczących się języka polskiego. Szczególną uwagę zwraca się na to, czy studenci potrafią prawidłowo odwzorować jej schemat poznany na lekcjach. Wnioski płynące $\mathrm{z}$ analiz mają więc ukazać skuteczność przyswajania przez nich tej formy pisemnej pod względem formalnym, choć są także obrazem nabytej wiedzy językowej: znajomości słownictwa, struktur gramatycznych i zasad poprawnego zapisu. Artykuł poświęcony został również takim zagadnieniom tekstowym, do których Teresa Dobrzyńska zaliczyła kwestie wyodrębniania wypowiedzi jako autonomicznej, wewnętrznie zorganizowanej całości (Dobrzyńska 1996, s. 126). Badania służą bowiem opisaniu sposobów rozpoczynania oraz kończenia charakterystyk przez cudzoziemców. Na końcu zaproponowane zostaną autorskie ćwiczenia przydatne obcokrajowcom w prawidłowej realizacji wzorca charakterystyki.

\section{PRZEDMIOT BADAŃ}

W niniejszych rozważaniach badana jest kompozycja charakterystyki przyjaciela - jej globalna struktura, podziały formalne, delimitacja tekstu oraz występowanie wypowiedzi metatekstowych. Autorami prac będących przedmiotem analizy są obcokrajowcy uczęszczający na kurs języka polskiego na poziomie A2 w Studium Języka Polskiego dla Cudzoziemców UŁ, różniący się względem 
siebie pochodzeniem, tempem uczenia się, stopniem motywacji itd. Analizie poddano trzydzieści osiem prac studentów. Autorzy pochodzili z dwóch grup o tym samym poziomie zaawansowania językowego, choć o różnych profilach: medycznym i humanistycznym. W czasie gromadzenia materiału badawczego zagadnienia poruszane na kursie języka polskiego były w obu grupach podobne i bazowały na języku ogólnym.

\section{KOMPOZYCJA CHARAKTERYSTYKI}

Kompozycja wypowiedzi językowej (z łac. compositio, czyli 'złożenie', 'układ') to budowa jej części składowych, uwydatnienie poszczególnych elementów treści, sterowanie uwagą odbiorcy (Zdunkiewicz-Jedynak 2008, s. 69), słowem - to, czym różnią się od siebie gatunki piśmiennicze (Wolańska 2003, s. 119).

Charakterystyka postaci, która cieszy się popularnością zarówno na lekcjach języka polskiego jako pierwszego, jak i drugiego, polega na zaprezentowaniu osoby pod względem wyglądu, zachowań, jej psychiki, postawy moralnej i światopoglądowej, także relacji między jej życiem wewnętrznym i właściwościami charakteru a cechami wyglądu i zachowaniami. Wyróżnia się charakterystykę bezpośrednią - formułowaną wprost przez podmiot mówiący oraz pośrednią - implikowaną przez słowa, myśli i działania samej postaci (Przygoda 2015, s. 22). Charakterystykę postaci określa się jako formę o dość luźnej konstrukcji, choć wskazuje się na jej trójdzielny układ (wstęp, rozwinięcie, zakończenie) oraz na stałą obecność następujących elementów:

- przedstawienie (prezentacja postaci);

- wygląd i zachowanie;

- cechy charakteru, usposobienie, temperament (wraz z przykładami lub motywacją czynów);

- zainteresowania, zdolności, poglądy;

- $\quad$ stosunek do innych ludzi;

- ocena postaci (Juda-Mieloch 2003, s. 29-30).

Zanim poproszono studentów o napisanie charakterystyk przyjaciela, przeprowadzono lekcje poświęcone temu tematowi. Wykorzystano (z pewnymi modyfikacjami) podręcznik Pisać jak z nut (Lipińska, Dąmbska 2016), na podstawie którego słuchacze dowiedzieli się, czym jest ta forma pisemna, czemu służy, jak ją pisać. Poznali niezbędne struktury gramatyczne, leksykę, przykłady charakterystyki bezpośredniej i jej wzorzec kompozycyjny, który obejmował:

- przedstawienie postaci;

- wygląd zewnętrzny;

- inne cechy: głos, sposób poruszania się, gestykulację, śmiech; 
- cechy charakteru, usposobienie;

- zainteresowania, uzdolnienia, umiejętności;

- ocenę, podsumowanie, komentarz.

\section{REALIZACJA WZORCA STRUKTURY CHARAKTERYSTYKI W PRACACH CUDZOZIEMCÓW}

Stopień opanowania przez studentów przekazanych na lekcji treści pokazała jakość ich charakterystyk. Na ogół uczący się komponowali swoje teksty, zawierając właściwe tej formie pisemnej elementy struktury.

Studenci przedstawiali postać, pisząc, jak przyjaciel ma na imię, gdzie mieszka (podając nazwy krajów, miast, konstrukcję domu), ile ma lat, czym się zajmuje, jakie ma plany na przyszłość, gdzie i kiedy piszący i jego przyjaciel się poznali. Np.:

Mam przyjaciółkę, ona ma na imię Vlada i teraz mieszka w Hiszpanii, ale kiedy byłyśmy dziećmi, mieszkały ${ }^{1}$ razem w Rosji (Byłyśmi sąsiadkami). Znam ją szesnaście lat, i teraz ona stała się jak część mnie. Na przykład jak ręka albo noga. Teraz ona ucze się w szkole (10 rok) i ma prawie siedemnaście lat.

Niektórzy słuchacze bardzo krótko przedstawili swojego przyjaciela, podając jedynie imię, np. „Ona ma na imię Nigar” lub imię i określenie wieku, mimo że podczas lekcji poznali bardziej rozbudowane konstrukcje. Lakoniczność jest często występującą cechą w analizowanych wypowiedziach pisemnych uczniów.

Opis wyglądu zewnętrznego w pracach studentów obejmował wskazanie na: wzrost, włosy (długość, kolor i fakturę), oczy (kolor), rzęsy, wygląd i mimikę twarzy, uśmiech, zęby, nos, uszy, czoło, szyję, budowę ciała (figurę), sposób ubierania się, karnację oraz kolory, w których jest do twarzy opisywanym przez studentów osobom. Uczący się przywoływali elementy wyglądu, stosując poznane na lekcjach struktury. Np.:

Jest osobą średniego wzrostu i wysportowaną. Jej włosy do pasa są zadbane proste i długie. W jej oczach, które są ciemnego koloru widać radość. Ubiera się wyszukanie i stylowo. Kolorem Diany jest pomarańczowy, stonowany, w odcieniu zachodzącego słońca.

Niekiedy gotowe konstrukcje przepisywali do prac z błędami, co świadczy o braku precyzyjności. Zdarzały się błędy ortograficzne, np. „geste rzesy”, „okrongla twarz”, „zwłascza, gdi”, ale także gramatyczne, np. „Taisia ma dluga, cienka szyja”, ,żeby nie męczyć swój wzrok”. Pojawiały się również błędy logiczne powstałe na skutek zastosowania skrótu, pominięcia istotnego elementu struktury, np. określenia - przymiotnika. Na podstawie poznanej frazy „Ma bar-

${ }^{1}$ Zachowano oryginalną pisownię i interpunkcję. Analiza błędów językowych popełnianych przez obcokrajowców nie jest przedmiotem niniejszego opracowania. 
dzo charakterystyczny śmiech - poznałbym go po nim na końcu świata!" jeden ze studentów napisał o swoim przyjacielu: „ma śmiech - poznałbym go po nim na końcu świata".

Słuchacze na ogół nie pomijali także opisu innych cech przyjaciela. Pisali, jaki jest jego głos czy sposób poruszania się, wskazywali na gestykulację lub śmiech, zwykle jednak wymieniając tylko te cechy, które zostały wspomniane w materiałach dydaktycznych wykorzystywanych podczas lekcji.

Ona ma niski i ciepły głos i bardzo miły śmiech. Jej sposób poruszania podobny do modelki: małe i eleganckie kroki.

Opis cech charakteru i usposobienia był tą częścią charakterystyki, w której studenci wykazali się największą kreatywnością i produktywnością. Dość dużo pisali o osobowości swoich przyjaciół, łącząc ją z przykładami zachowań.

Jest ambitna i pracowita, dlatego w przyszłości chciałaby otworzyć schronisko.

Tutaj słuchacze ujawniali swoją obecność, pisząc np.:

Ja zawsze może jej ufać. Ona jest taktowna i zawsze wie kiedy nie mam nastroju. Kiedy mam jakiś problem, ona daje mi rady.

Zdarzało się jednak, że opisanie cech charakteru i usposobienia przybierało postać wyliczeń.

Anja jest tolerancyjna, miła, ambitna, sympatyczna, rozrzutna, nerwowa i naiwna. Ma duże poczucie humoru.

Studenci chętnie pisali na temat zainteresowań, uzdolnień i umiejętności swoich przyjaciół. Wskazywali na sposoby spędzania wolnego czasu.

Kristi zna dużo języków obcych i w wielu krajach ma przyjacielów. Ona jest sportywna.

Lubi grać w siatkówkę. Też ona lubi chodzić w góry i bardzo lubi przyrodę.

Choć studenci na ogół uwzględniali wszystkie elementy kompozycji charakterystyki postaci, to nie zawsze umieszczali je w odpowiedniej kolejności, więc nie stosowali prawidłowo jej wzorca. Ukazują to fragmenty, w których brak jest spójności - mieszają się opisy ilustrujące charakter, osobowość, usposobienie oraz zainteresowania, uzdolnienia i umiejętności lub wygląd.

Mój przyjaciel jest bardzo emocjonalny, wesoły i optymistycznie nastawiony do życia.

Ma duże poczucie humoru, nie ma więc wrogów. Uwielbia biegać, tańczyć, grać w koszykówkę. Interesuj się sportem. Największą wadą Wani jest trochę arogancki, ale łatwo jemy to można wybaczyć, bo jest naprawdę dobry i inteligentny chłopakiem.

Były również prace, które w swojej strukturze przypominały bardziej charakterystykę pośrednią niż bezpośrednią. Autorka jednej z nich wykorzystała opis sytuacji, aby ukazać łączące ją i przyjaciółkę relacje, nie nazywając wprost cech bliskiej osoby lub stosując takie określenia bardzo oszczędnie. Warto jednak docenić jej umiejętność stosowania rozbudowanych struktur składniowych oraz kreatywność językową.

Jesteśmy na tym etapie relacji, że kiedy, na przykład, ona oblałaby się na imprezie czerwonym winem, ja zrobiłabym jej zdjęcie, a potem oblałabym sama, znowu zrobiłabym 
zdjęcie $^{2}$, i razem pojechałybyśmy do domu, żeby oglądać serialy. Kiedy spotykamy w czasie ferii, zawsze robimy wszystko razem. Chociaż możemy nie powiedzieć sobie nawzajem za cały dzień i jednego słowa, jesteśmy bardzo bliscy. Była taka sytuacja (...).

\subsection{DELIMITACJA CHARAKTERYSTYKI POSTACI (SPOSOBY JEJ ROZPOCZYNANIA I KOŃCZENIA)}

Delimitacja tekstu, czyli obecność wykładników jego punktów granicznych - zarówno początku, jak i końca - odgrywa szczególną rolę komunikacyjną w strukturze tekstu. Ich odczytanie jest ważne zwłaszcza przy odbiorze i analizie różnych wypowiedzi, bowiem sprawiają, że wypowiedź ta jawi się jako pełny pojedynczy tekst, nie zaś jako fragment lub zlepek części różnych całości. Odgraniczają to, co jest tekstem od tego, co nim nie jest (Dobrzyńska 1974, s. 5).

Jego sposób otwarcia nazywany jest pierwszoplanową pozycją strategiczną, na nim bowiem skupia się zwiększona uwaga odbiorcy (Wolańska 2003, s. 125). W pracach obcokrajowców, poza kilkoma przykładami, tekst otwierały delimitatory wtórne, czyli znaki, które nie przekazują zwerbalizowanej informacji o jego granicach (np. zacznę od ... lub na początku ...) (Dobrzyńska 1974, s. 6). Sygnałami początku były najczęściej konstrukcje zawierające zaimek dzierżawczy mój, przymiotniki w stopniu najwyższym: najlepszy, najbliższy i rzeczowniki przyjaciótka, koleżanka oraz wskazanie na imię, choć zdarzały się także inne formuły inicjalne.

Moja najlepsza przyjaciółka ma na imię Krystyna.

Wśród zdań inicjalnych w badanym zbiorze tekstów obecne było jedno zdanie zawierające leksykalny sygnał otwarcia (sygnał początku). Był nim delimitator właściwy:

Na początku chciałabym powiedzic, że mam nie mało przyjaciół. Ale teraz chciałabym napisać o przyjaciółce, z którą poznałam się w szkole, kiedy miałam sześć lat ${ }^{3}$.

Jedynie w dwóch pracach występował tytuł i tylko w jednej z nich odzwierciedlał temat tak, że czytelnik mógł na jego podstawie określić ogólną zawartość pracy.

Moja przyjaciółka

${ }^{2}$ Studentka wykorzystała przykład zachowania z quizu na dobrego przyjaciela, przyjaciółkę. Patrz: Burkat, Jasińska 2005.

3 Cytowany fragment to przykład metatekstu, czyli występowania w tekście wyrażeń, komentarzy o nim samym, w których ujawnia się nadawca-autor. Są to m.in. tworzące ramę wypowiedzi pisemnej uwydatnienia poszczególnych elementów kompozycji, tzw. tranzycje (np. na początek, na końcu, po pierwsze, po drugie, zanim przejdę do), jak w cytowanym zdaniu oraz wyodrębnione kompozycyjnie części tekstu, jak: tytuł, motto, przypisy, zestawy bibliograficzne, fragmenty cudzysłowowe (Zdunkiewicz-Jedynak 2008, s. 69). 
$\mathrm{W}$ jednej z charakterystyk tekst właściwy poprzedziło motto, stanowiące myśl przewodnią całości pracy.

Powiedz mi, kim są twoi przyjaciele, a powiem ci, kim jesteś Ernest Hemingwaja.

Jeden tekst został zainicjowany sentencjonalnym zdaniem zawierającym kwantyfikator kazdy. O takich zdaniach pisała Maria Krauz, nazywając je wypowiedzeniami o ogólnym odniesieniu i wyjaśniając, że często otwierają tekst, bo są także wypowiedzeniami pełnymi formalnie i zrozumiałymi (Krauz 1996, s. 85).

W życiu każdego człowieka musi być przyjaciel.

Analiza zdań inicjalnych w charakterystykach przyjaciela pokazała, że studenci nie przywiązują dużej wagi do sposobów rozpoczynania prac pisemnych. Do rzadkości należy pisanie wstępów, wykorzystujących pewne interdyscyplinarne odwołania, wywołujących u odbiorcy efekt zaskoczenia, zdziwienia, co zdarzało się w przypadku innych form pisemnych tych samych autorów.

Badając sygnały wyznaczania granic tekstu, należy zwrócić uwagę tak na wyrażenia służące nawiązaniu kontaktu językowego, jak i jego rozwiązaniu (Dobrzyńska 1996, s. 126-127). Wśród zdań kończących wypowiedź pisemną są m.in. te wyodrębnione przez studentów w strukturze tekstu, np. stanowiące osobny akapit, będące podsumowaniem, komentarzem wcześniejszych słów i zarazem nawiązaniem do tematu pracy. Podkreślają, kim jest dla autorów opisywana osoba i wskazują, jak ważna jest dla nich ta relacja.

Bardzo lubię moją przyjaciółkę, ponieważ ona jest częścią mnie i zawsze wspiera mnie.

Mieć taką przyjaciółkę to szczęście.

W charakterystykach przyjaciela można wyróżnić również zdania kończące wypowiedź pisemną, będące właściwie jej kontynuacją (np. stanowią dalszy ciąg mówienia o zainteresowaniach, umiejętnościach czy sposobach spędzania wolnego czasu). Ani pod względem graficznym, ani przekazywanej treści nie odróżniają się od całości pracy.

Prawie codziennie po parach szliśmy razem do domu.

W zakończeniach dało się również zauważyć podobne struktury pod względem semantycznym do tych, które wcześniej występowały w tekście. Zdaniem otwierającym charakterystykę było np.: „Moja najlepsza koleżanka ma na imię Kasia”, zaś zamykającym ją: „Kasia naprawdę jest mojej najliepszą koleżanką”. Analizowane finały tekstu zwykle nie były bogate pod względem treściowym. Najczęściej brakowało w nich oceny postaci czy syntetycznego, globalnego ujęcia wniosków. 


\section{PROPOZYCJA ĆWICZEŃ ROZWIJAJĄCYCH SPRAWNOŚĆ PISANIA}

Analiza przedstawionych przykładów ukazała pewne niedoskonałości w wykonanym przez studentów zadaniu, dlatego zaproponowano kilka autorskich ćwiczeń przydatnych cudzoziemcom w prawidłowej realizacji schematu charakterystyki.

Znajomość samych wzorców stylistycznych nie wystarczy do poprawnego komponowania wypowiedzi pisemnych. Nieodzowne są m.in.: bogate słownictwo, odpowiednie struktury gramatyczne, zasady poprawnego zapisu itd. Pierwsze zaproponowane ćwiczenie pozwoli ugruntować nabytą wiedzę językową studentów, wykorzystując przy tym ich kreatywność. Uczniowie podzieleni na pięć grup otrzymują zdjęcie postaci, którą mają scharakteryzować pod określonym względem. Przebieg zadania przedstawia tabela.

\section{Proszę scharakteryzować postać.}

\begin{tabular}{|c|c|c|c|}
\hline Grupa & Postać & Zadanie & Przykład realizacji ${ }^{a}$ \\
\hline 1 & Fryderyk Chopin & $\begin{array}{l}\text { przedstawienie } \\
\text { postaci }\end{array}$ & $\begin{array}{l}\text { kompozytor, pianista, } \\
\text { Polak, mieszkaniec } \\
\text { Francji itd. }\end{array}$ \\
\hline 2 & Leonardo DiCaprio & wygląd zewnętrzny & $\begin{array}{l}\text { przystojny, wysoki, } \\
\text { szczupty, szatyn itd. }\end{array}$ \\
\hline 3 & Rowan Atkinson & $\begin{array}{l}\text { inne cechy: głos, } \\
\text { sposób poruszania } \\
\text { się, gestykulacja, } \\
\text { śmiech }\end{array}$ & $\begin{array}{l}\text { wyrazista mimika, } \\
\text { bogata gestykulacja, } \\
\text { mowa ciała, } \\
\text { charakterystyczny } \\
\text { śmiech (uśmiech), } \\
\text { poczucie humoru itd. }\end{array}$ \\
\hline 4 & Cristiano Ronaldo & $\begin{array}{l}\text { cechy charakteru, } \\
\text { usposobienie }\end{array}$ & $\begin{array}{l}\text { energiczny, } \\
\text { spontaniczny, } \\
\text { ambitny itd. }\end{array}$ \\
\hline 5 & $\begin{array}{c}\text { Maria Skłodowska- } \\
\text {-Curie }\end{array}$ & $\begin{array}{l}\text { zainteresowania, } \\
\text { uzdolnienia, } \\
\text { umiejętności }\end{array}$ & $\begin{array}{l}\text { fizyka, chemia, } \\
\text { nagroda Nobla itd. }\end{array}$ \\
\hline
\end{tabular}

a Ta część tabeli przedstawia jedynie bank słów, który należy wykorzystać do tworzenia całych zdań, opartych na prawidłowych i zróżnicowanych strukturach gramatycznych, poprawnym zapisie etc.

Nauczyciel może zdecydować się na jedną postać - powstanie wówczas jedna, ale kompletna i modelowa charakterystyka. 
Aby zwrócić uwagę studentów na to, jak ważna jest spójność tekstu i uwrażliwić na właściwą kolejność przedstawianych w charakterystyce treści, można zaproponować ćwiczenie polegające na usuwaniu niepasujących fragmentów. Są to zdania lub ich części, które znalazły się w niewłaściwym miejscu w tekście albo w ogóle nie powinny wystąpić w charakterystyce bezpośredniej.

\section{Proszę usunąć z tekstu niepotrzebne informacje.}

Moja przyjaciótka ma na imię Karolina. Poznałyśmy się w szkole i przyjaźnimy się już trzy lata. Studiuje dziennikarstwo i ekonomię. Ma 20 lat imily uśmiech.

Karolina jest średniego wzrostu. Lubi jeśé stodyeze. Najbardziej lody i gofry. Ma ładna, pociagła twarz, maty nos i niebieskie oczy. Jej blond włosy sięgają do pasa. Często wiąże je w kitkę. Jej oezy sa duże.

Moja przyjaciółka ma miły, spokojny głos, ale czasami, gdy denerwuje się na swojego młodszego brata, głośno krzyczy. Ma poczucie humoru i często się śmieje. Swoim śmiechem zaraża innych.

Ona jest pilna $i$ ambitna. Ładnie się ubiera. Jest jedna z najlepszych studentek. Po skończeniu studiów chce pracować w telewizji. Jest uparta i robi wszystko, aby spetnić swoje marzenia. Jest również zdolna i utalentowana językowo, dlatego bardzo szybko uczy się języków obcych. Zna świetnie język angielski, dobrze hiszpański, a niedawno zaczęła uczyć się niemieckiego. Ja nienawidze niemieckiego. Kiedyś wezylam się go w szkole, ale Karolina ma też wady-jest niepunktualna. Bardzo często przychodzi na nasze spotkania spóźniona. Ostatnio, pamiętam, umówilyśmy się w Manufakturze 0 17:00, a ona przyszla pót godziny później, bo za dtugo utatata wosy. Nawet mie nie przeprosila! Bywa tez roztargniona. Nie pamięta, gdzie coś zostawiła $i$ wtedy pyta mnie. Nieraz bardzo dlugo czegoś szuka i nie może znaleźć. Fak by mi to ką, która pożyezyla koleżance - Monice, a później Monika pożyezyla ja swojej siostrze.

Moja przyjaciótka interesuje się muzyką. Kiedyś chodziła do szkoły muzycznej. Fest wysportowana. Lubi podróżować, czytać książki i uczyć się języków obcych. Ma ladna syleter.

Karolina jest moja jedyna przyjaciótka. Bardzo lubię spędzać z niq czas. Bardzo się cieszę, że ja poznałam.

W budowaniu spójnego, uporządkowanego, logicznego tekstu pomóc może również ćwiczenie, w którym należy uzupełnić charakterystykę bezpośrednią właściwymi, brakującymi fragmentami. Propozycje zdań mogą być podane lub nie.

\section{Proszę uzupelnić tekst brakującymi fragmentami, wybierając je z ramki.}

\begin{tabular}{|cc|}
\hline To optymistka. & Lubię stuchać, gdy coś opowiada. \\
Jest bardzo tadna. & Ma duże poczucie humoru. \\
To moja sąiadka. & Ma talent kulinarny. \\
Zawsze mogę na nia liczyć. & Jest zgrabna. \\
\hline
\end{tabular}

Moja przyjaciótka jest Paulina. . . . To moja sąsiadka. . . . Razem chodzityśmy do szkoty. Ma 25 lat.

Paulina jest niska, szczupła szatynka. . . . Jest bardzo ładna. . . . Ma ciemne oczy, maty, lekko zadarty nos $i$ waskie usta. Jej zęby byty krzywe i dlatego teraz nosi aparat ortodontyczny. . . . Jest zgrabna. . . . Ma idealna figure, bo uprawia sport. 
Moja przyjaciółka ma mity, spokojny głos. .... Lubię stuchać, gdy coś opowiada. . . . Często żartuje, a jej śmiech jest zabawny.

Paulina jest wesoła, dowcipna. ... . Ma duże poczucie humoru. . ...... . To optymist$k a . . . .$. Często powtarza, że wszystko będzie dobrze. Jest bardzo towarzyska i gościnna. Lubi zapraszać koleżanki, kolegów i często dla nich gotuje. . . . . Ma talent kulinarny. . . . Potrafi ugotować coś dobrego, nawet gdy w lodówce brakuje produktów.

Cieszę się, że mam taka przyjaciółkę jak Paulina. . . . Zawsze mogę na nia liczyć. . . . .

Aby utrwalić właściwy schemat charakterystyki bezpośredniej, można również zaproponować ćwiczenie polegające na układaniu fragmentów tekstu w odpowiedniej kolejności.

\section{Proszę uszeregować informacje w kolejności wlaściwej charakterystyce.}

1. Mój przyjaciel ma imię Piotr.

2. To mój wspótlokator.

3. Jest wysokim, dość krępym blondynem.

4. Dużo gestykuluje - jak Włoch - gdy coś opowiada.

5. Jest wesoty, dowcipny i gadatliwy.

6. Bardzo lubi piłkę nożną. Jest fanem Realu Madryt.

7. Sam też świetnie gra.

8. Ma kilka wad, ale jest bardzo dobrym przyjacielem.

Aby pokazać studentom różnicę pomiędzy charakterystyką pośrednią a bezpośrednią i zapobiec mieszaniu się tych dwu form, można posłużyć się tabelą. Po jednej stronie znajdą się frazy charakterystyczne dla charakterystyki pośredniej, czyli opisy postaci zawarte w czynach lub myślach danej osoby albo w opiniach innych ludzi. Po drugiej zaś obecne będą określone elementy opisu nazwane wprost. Można zaproponować łączenie kolumn albo, dla bardziej wprawnych studentów, ich samodzielne uzupełnianie.

\section{Proszę uzupelnić tabelkę.}

\begin{tabular}{|l|l|}
\hline \multicolumn{1}{|c|}{ Charakterystyka pośrednia } & Charakterystyka bezpośrednia \\
\hline $\begin{array}{l}\text { Bardzo dobrze opiekował się psem, którego znalazł } \\
\text { na ulicy. Przygotowywał mu dobre jedzenie, często } \\
\text { wyprowadzał na spacery i zabierał do weterynarza, } \\
\text { gdy była taka potrzeba. }\end{array}$ & Był troskliwy i opiekuńczy. \\
\hline $\begin{array}{l}\text { Leżała przed telewizorem całymi dniami. Często } \\
\text { zasypiała w ubraniu, bo nie chciało jej się wstać. } \\
\text { Nie odrabiała prac domowych, nie uczyła się, nie } \\
\text { pomagała rodzicom w domu. }\end{array}$ & Była leniwa i nieobowiązkowa. \\
\hline $\begin{array}{l}\text { Wczoraj kolega z pracy powiedział Annie coś } \\
\text { niemiłego i ona cały czas płacze. Nie może przestać } \\
\text { o tym myśleć. Jest jej przykro. Nie chce wyjść } \\
\text { z koleżanką do pubu. Nie ma na nic ochoty. }\end{array}$ & Jest wrażliwa, smutna, przygnębiona. \\
\hline
\end{tabular}




\section{ZAKOŃCZENIE}

Charakterystyka jest jedną z zalecanych form pisemnych podczas nauki języka polskiego obcokrajowców na poziomie A2. Autorzy Programów nauczania języka polskiego jako obcego (Rabiej i in. 2006, s. 60) twierdzą bowiem, że uczący się na tym poziomie zaawansowania powinni już m.in. wskazywać cechy; wyrażać, pozytywne, negatywne i neutralne opinie czy wyrażać sympatię i antypatię. Braki w zakresie słownictwa, ortografii, interpunkcji czy poprawności gramatycznej nie powinny zaś wpływać na zrozumiałość komunikatu.

Znajomość większej, niż zaprezentowana, liczby przykładów pozwala stwierdzić, że obcokrajowcy na ogół budowali charakterystykę przyjaciela zgodnie z przedstawionym na lekcjach schematem. Wykorzystywali także podane na lekcjach struktury gramatyczne oraz leksykę, niekiedy jednak bezrefleksyjnie, niedokładnie - błędnie przepisując je do swych prac. Teksty rzadko były bogate pod względem treściowym, częściej - oszczędne w stosowaniu nowych form. Niekiedy występowały struktury eliptyczne, pozbawione czasowników. Na charakterystykę składało się wówczas wyliczenie cech opisywanego człowieka.

Najczęstsze błędy w realizacji wzorca charakterystyki bezpośredniej reprezentowały prace, w których autorzy mieszali poszczególne elementy opisu, tworząc niespójny, nieuporządkowany, źle wewnętrznie zorganizowany komunikat słowny. Zdarzały się również teksty przypominające bardziej charakterystykę pośrednią niż bezpośrednią, gdy autorzy opisywali jedynie zdarzenia lub działania przyjaciela implikujące określone cechy bez nazywania ich wprost. Odstępstwem od prawidłowej realizacji omawianej formy pisemnej było również nadmierne manifestowanie swojej obecności przez autorów, którzy zamiast przyjaciela prezentowali siebie.

Większość początków i zakończeń charakterystyk przyjaciela pisanych przez cudzoziemców uczących się języka polskiego jako obcego pełniła funkcję delimitacyjną, ale rozpoczęcia i finały tekstu nie były bogate pod względem treściowym, bowiem często składały się z jednego krótkiego zdania. W zakończeniach można było zauważyć podobne struktury pod względem semantycznym do tych, które występowały wcześniej w tekście. W zakończeniach brakowało oceny postaci, syntetycznego, globalnego ujęcia wniosków.

Wynika stąd, że przeprowadzone lekcje nie wystarczyły, aby studenci odpowiednio wykonali powierzone zadanie. Potrzeba zwrócenia uwagi na powtarzające się błędy i chęć zapobiegnięcia ich występowaniu w przyszłości doprowadziły do stworzenia kilku autorskich ćwiczeń pomocnych w prawidłowej realizacji wzorca charakterystyki bezpośredniej. 


\section{BIBLIOGRAFIA}

Burkat A., Jasińska A., 2005, Hurra!!! Po polsku 2. Podręcznik studenta, Kraków.

Dobrzyńska T., 1974, Delimitacja tekstu literackiego, Wrocław.

Dobrzyńska T., 1996, Tekst w perspektywie stylistycznej, w: T. Dobrzyńska (red.), Tekst i jego odmiany, Warszawa, s. 125-141.

Duszak A., 1998, Tekst, dyskurs, komunikacja międzykulturowa, Warszawa.

Jaroszak Z., 2003, Składania i styl wypracowań licealistów, Słupsk.

Juda-Mieloch M., 2003, Wędrówki humanistyczne. Trzymaj formę! O pisemnych formach wypowiedzi w szkole, Łódź.

Kaczorowska H., Ruszkowski M., 1996, Udział wypowiedzeń pojedynczych i złożonych $w$ tekstach pisanych uczniów klas VII szkót miejskich i wiejskich województwa kieleckiego, „Kieleckie Studia Filologiczne", nr 10, s. 71-76.

Kowalikowa J., 1999, Świadomość normy stylistycznej wśród nauczycieli i uczniów, w: J. Miodek (red.), Mowa rozświetlona myśla. Świadomość normatywno-stylistyczna wspótczesnych Polaków, Wrocław, s. 149-158.

Krauz M., 1996, Zdania inicjalne w języku polskim, Rzeszów.

Kubik A., 1995, Niektóre cechy wypowiedzi pisemnych uczniów klasy trzeciej szkoły podstawowej, w: J. Ożdżyński (red.), Językowy obraz świata dzieci i młodzieży, Kraków, s. 344-351.

Kuziak M., Rzepczyński S., 2002, Jak dobrze napisać: opowiadanie, podanie, streszczenie, życiorys, ogłoszenie, list motywacyjny, podziękowanie, referat, pracę magisterska, Warszawa.

Lipińska E., Dąmbska E. G., 2016, Pisać jak z nut. Podręcznik rozwijający sprawność pisania. Dla obcokrajowców na poziomie B1+/B2, Kraków.

Maćkiewicz J., 2010, Jak dobrze pisać. Od myśli do tekstu, Warszawa.

Małkowska-Zegadło H., 1983, Rozwój języka mówionego i pisanego uczniów w wieku 8-11 lat, Warszawa.

Nowak E., 2014, Stworzyć tekst. Uczniowska kompetencja tekstotwórcza w edukacji polonistycznej, Kraków.

Pilich J., 1972, Btędy gwarowe w wypracowaniach, w: Z. Saloni (red.), Prace pisemne z języka polskiego w szkole średniej, Warszawa, s. 181-200.

Przygoda J., 2015, Od opisu do eseju. Pisemne formy wypowiedzi, Białystok.

Rabiej A., Seretny A., Lipińska E., Janowska I., Turek P. (red.), 2016, Programy nauczania języka polskiego jako obcego. Poziomy A1-C2, Kraków.

Saloni Z., 1968, Błędy uczniowskie w zakresie konstrukcji dtuższych odcinków tekstu, „Poradnik Językowy", nr 1, s. 32-39.

Saloni Z., 1971, O ortografii wypracowań, „Poradnik Językowy”, nr 7, s. 462-471.

Saloni Z., 1975, O stylu wypowiedzi uczniowskich, „Poradnik Językowy”, nr 3, s. 151-157.

Tabisz A., 2006, Kompetencja tekstotwórcza uczniów na przykładzie rozprawki, Opole.

Wolańska E., 2003, Kompozycja i spójność wypowiedzi językowej. Strategiczne pozycje tekstowe, w: E. Bańkowska, A. Mikołajczuk (red.), Praktyczna stylistyka nie tylko dla polonistów, Warszawa, s. 119-148.

Zdunkiewicz-Jedynak D., 2008, Wyktady ze stylistyki, Warszawa.

Zok-Smoła A., 2013, Uwagi o stylu wypowiedzi pisemnych uczniów szkót podstawowych, w: H. Synowiec, M. Kubarek (red.), Odmiany polszczyzny w szkole: teoria i praktyka, Katowice, s. 189-201. 
Justyna Sochacka

\section{THE STRUCTURE OF DESCRIPTIVE ESSAY ABOUT A PERSON AND ITS REALIZATION IN COMPOSITIONS WRITTEN BY STUDENTS LEARNING POLISH AS A FOREIGN LANGUAGE AT THE A2 LEVEL}

Keywords: descriptive essay about a person, textual competence, textual creation competence, texture, teaching methodology, teaching Polish as a foreign language, foreigner

Abstract. The article reflects on the text-based issues connected with producing chosen written forms in Polish as a foreign language classroom. It discusses the structure of a composition describing one's friend written by students who learn Polish in the School of Polish for Foreigners at the University of Lodz. The article shows the global structure of these forms, their division, text delimitation and the use of metatext. It also analyses the degree of students' mastery of the new composition skills that had been acquired in writing classes. It gives some examples of exercises, which are useful in teaching the structure of the descriptive essay about a person. 